\title{
The Future of Trans-Tasman Closer Economic Relations
}

\author{
Peter Lloyd
}

$\mathrm{T}$

The Closer Economic Relations Agreement (CER) between Australia and New Zealand has already achieved some notable successes in relation to non-border policies as well as the traditional coverage of trade liberalisation; and it is the most clean and the most outwardly open of all of the regional trading arrangements approved under the GATT.

Yet CER is at a turning point, for two reasons. One is the question of how far the harmonisation of domestic policies should go: is the Agreement basically about free trade or does it seek to promote further integration of the two economies? The other reason lies in the Agreement's relationships with other regional agreements, particularly the ASEAN Free Trade Area (AFTA), the North American Free Trade Area (NAFTA) and the Asia Pacific Economic Cooperation forum (APEC).

\section{The Provisions of CER}

When it came into effect on 1 January 1983, CER $^{1}$ was planned to bring about a genuine and complete free trade area by 1995. In the event, all border barriers were eliminated by 1 July 1990 . Moreover, the Agreement has progressed well beyond the removal of border barriers. A review in 1988 added a Protocol on Trade in Services, which extended the liberalisation of border trade to trade in services, including national treatment in relation to all laws, regulations and practices as well as free market access. It also removed major non-border restrictions on international trade in goods, and introduced a comprehensive structure of harmonisation of instruments affecting the commercial environment so as to remove impediments to the growth of trade and competition within the area and to enhance the capacity of producers in both countries to compete on world markets. The 1988 Review and a second Review in 1992 amounted to a major extension of the Agreement.

\footnotetext{
${ }^{1}$ Australian Department of Foreign Affairs and Trade (1991) reproduces the CER and all of the amending documents arising from the 1988 Review. The Joint Statement and exchanges of letters resulting from the 1992 Review are reproduced in the New Zealand Ministry of External Relations and Trade (1992a,b).
}

Peter Lloyd is Director of the Asian Business Centre at the University of Melbourne. 
To handle sensitive areas of trade in services, CER used the device of a 'negatives' list, that is, the exemption only of specified services from the provisions, similar to the approach in NAFTA. In contrast, the 1988 Canada-US Free Trade Area used a 'positives' list. Australia initially exempted substantially more services than New Zealand, partly on the grounds that a number of these were subject to enquiries and proposals for deregulation or reform. But the list of inscriptions has been reduced.

The non-border instruments covered by the CER comprised national subsidies, government purchasing and antidumping provisions. The Agreement itself did not proscribe national subsidies or other forms of assistance to industries, and it permitted the use of countervailing measures. As a part of the 1988 Agreed Minute on Industry Assistance that ended export subsidies on trade between the two countries, it was agreed that neither Australia nor New Zealand would pay production bounties or like measures on goods exported to the other country under a number of then existing programs and that they would endeavour to avoid the adoption in future of industry-specific measures that would have adverse effects on competition between industries in the Free Trade Area. The notification and consultation procedures of the Agreed Minute were strengthened in an exchange of letters as a part of the 1992 Review. This is a stronger restriction on subsidies as an instrument of assistance than exists in any other regional trading arrangement, including the European Union (EU).

In relation to government purchasing, the original Agreement required the two governments to extend to each other any tariff preferences that applied on goods purchased by government buyers; but this did not imply zero tariffs or equality of opportunities to tender and compete. Complete equality was achieved when New Zealand joined the Australian National Preference Agreement between the Commonwealth and State Governments on a nil preference basis from 1 June 1989, with New Zealand reciprocating the benefits.

Antidumping actions by the two countries against one another were eliminated on 1 July 1990 . Henceforth, each country must rely upon competition law to act against unfair trading with the other.

Article 12 of the Agreement declared that the two countries would 'examine the scope for taking action to harmonise requirements relating to such matters as standards, technical specifications and testing procedures, domestic labelling and re-

\footnotetext{
${ }^{2}$ Since 1 January 1989 free trade has been extended to more services. In July 1991 Australia removed Construction, Engineering and General Consultancy (which received Australian government preferences) from the inscriptions list and in October 1991 it reduced the coverage of the Telecommunications exemption. In September 1992, Australia removed Banking from the list. In June 1992, New Zealand removed Radio and Television Broadcasting and Shortwave and Satellite Broadcasting from the list and reduced the restrictions on the groups of Aviation, Postal services and Shipping services. From July 1991 the title of the National Preference Agreement was changed to 'Government Procurement Agreement' to reflect the inclusion of all services in the government procurement provisions and this was extended to CER as New Zealand became a party to this Agreement. Further liberalisation of services will occur as the 1994 review of inscriptions to the Protocol is implemented.
} 
strictive trade practices . . . CER provides a framework for cooperation between relevant authorities in the two countries and encourages the use of 'best endeavours' towards this end rather than requiring harmonisation. Considerable debate has occurred in Australia and New Zealand, as in the EU and in the US and Canada, about the meaning of 'harmonisation'. The prevalent view is that harmonisation shall not generally mean 'uniformity' or 'replication' - a view embodied in the agreements on customs procedures and industrial standards before the $1988 \mathrm{Re}-$ view and the areas of quarantine administrative procedures, customs policies and procedures, technical barriers to trade and business law that were included in the 1988 Review. For example, Article 8 of the Memorandum of Understanding on Harmonisation of Business Law states explicitly that 'Both Governments recognise that effective harmonisation does not require replication of laws, although that may be appropriate in some cases'. However, the Joint Understanding on Harmonisation of Customs Policies and Procedures states that the countries shall adopt 'common approaches wherever appropriate'.

During the 1992 Review period, business law was further harmonised, notably in the more extensive arrangements for enforcing each country's judgments and orders in the other country, harmonisation of elements of mutual assistance between business regulatory agencies, consumer sales legislation and financial reporting. The Review incorporated the October 1991 agreement establishing the Joint Accreditation System of Australia and New Zealand (JAS-ANZ), which it is hoped will lead to the development of uniform technical standards and certification practices.

Another major initiative that was taken in 1992 is not yet completed. The Mutual Recognition Agreement between the Commonwealth, State and Territory Governments of Australia of 11 May 1992 contained an invitation to New Zealand to consider participation in a trans-Tasman mutual recognition scheme. A joint transTasman Discussion Paper has been released and, if agreement is reached, a transTasman Mutual Recognition Agreement will be signed in late 1995 (Council of Australian Governments and the Government of New Zealand, 1995). This proposal was modelled on the Mutual Recognition in the EC '92 measures; if they are adopted, CER will be the only regional trading arrangement outside the EU with mutual recognition of standards and labour qualifications.

The outcome has been a considerable convergence of policies and procedures in the areas covered by these harmonisation agreements. CER has gone further in these respects than any regional trading arrangement other than the EU. Particularly notable is the Understanding on Harmonisation of Business Law, which is a little broader in scope than the areas of business law covered by the 1985 White Paper of the EC (Commission of the European Communities, 1985) since it in-

3 One of the purposes of setting up JAS-ANZ was to facilitate mutual recognition of conformance assessment with the EU. Australia and New Zealand, along with Canada and the US, are among the three priority countries or country groupings with which the EU is currently negotiating such an agreement. 
cludes all of the major areas of the White Paper and some others such as securities and futures law and commercial arbitration and the laws relating to the sale of goods. Progress has been marked in the difficult area of competition policy; the New Zealand legislation is now based substantially on the Australian Trade Practices Act. Changes to the Australian Trade Practices Act and the New Zealand Commerce Act prohibit persons with a dominant position in the market of either country from using that position to affect adversely either market, though the tests of market dominance and the coverage of the Acts differ.

\section{Foreign Investment and Labour Movements}

Neither the 1983 Agreement nor the extensions under the 1988 and 1992 Reviews contain any significant provisions relating to the free movement of labour or capital. A separate agreement known as the Trans-Tasman Travel Arrangements guarantees free movement of citizens and residents. This arrangement dates back to colonial times, but it was not formally adopted until the 1920 s and has been modified subsequently. Intra-area labour mobility has facilitated the reallocation of resources that accompanies the freeing of trade, leading to more efficient production in both countries and a larger aggregate area product. The arrangement also provided the foundation of the provision for national treatment of service providers in the Protocol on Trade in Services.

During the 1992 Review and subsequently, discussions have been held on proposals to develop a trans-Tasman pre-clearance regime and on the more ambitious proposal for a common aviation entry border that would treat trans-Tasman travel as domestic travel (the latter was a part of the single aviation market proposal in Australian Prime Minister Keating's One Nation Statement of February 1992). Neither has been agreed upon and significant differences remain between the two governments in this area, although work is continuing on the pre-clearance regime.

CER is unique in having achieved free trade in goods and in labour but not in capital. The EU, the Canada-US Free Trade Agreement (CUSTA), NAFTA and ASEAN all have provisions that relate to the movement of capital within the areas. In the case of the EU, the Treaty of Rome included 'capital' as one of the 'four freedoms', and the 1992 measures were intended to remove remaining barriers to the complete freedom of movement of capital in the EU. In the case of the other agreements, the provisions seek to promote greater, but not complete, freedom of capital movement. One of the objectives of NAFTA is to "increase investment opportunities'; the Agreement contains an Investment Chapter which provides national treatment (including rights of establishment, Most Favoured Nation [MFN] treatment, free movement of funds and binding arbitration), prohibits expropriation except for 'public purposes' and imposes a number of performance requirements (though exceptions are permitted to rights of establishment).

An agreement on investment was raised in the 1988 Review but it was considered inappropriate, mainly because the Australian government insisted that any bilateral preference agreement in this area would breach the Basic Treaty of Friendship and Cooperation between Australia and Japan. One small concession under 
CER promotes bilateral capital flows. In July 1990 the two countries restated their commitment to including CER benefits in the national-interest tests which are used to evaluate those foreign investments subject to approval under the foreign investment regulations of the two countries.

As with commodity trade, and in line with trends in almost all countries, both Australia and New Zealand have unilaterally and substantially liberalised foreign investment regulations during the period of operation of CER. Both countries have signed the OECD National Treatment Instrument, which guarantees national treatment for all foreign investors with some listed exceptions, removed foreign exchange controls on capital movements, and relaxed restrictions on entry of foreign investors. The main restrictions remaining relate to rights of establishment under the foreign investment controls and other acts that regulate service industries such as telecommunications and shipping and primary industry statutory marketing authorities in both countries.

\section{The Unusual Style of CER}

The upshot of these developments is that CER has some unusual features. As a form of regional trading arrangement, CER is very advanced and second only to the $\mathrm{EU}$ in terms of the extent of liberalisation of trade and harmonisation of nonborder instruments. In relation to the harmonisation of non-border polices, the EU is more advanced in terms of progression in some respects, notably a common external tariff and harmonisation of excise and value-added tax rates, a common market for all services, and free trade in capital flows. In a few areas of integration the CER is more advanced than the EU; these include the agreement to abolish subsidies and bounties that affect intra-area trade, and some areas of business law, especially competition law. (Lloyd, 1991:Table 3.2, compares the single market features of the EU and the CER. This comparison was not affected by the 1992 Review.)

The rules of CER are quite simple and brief compared with other advanced regional trading arrangements such as the EU, European Economic Area (EEA), CUSTA and NAFTA. CER was planned as a trade agreement that would require low maintenance and a minimum of bureaucratic resources. This is exemplified by the safeguard provisions and the rules of origin. There are no safeguard provisions apart from the modified applications for specified industries and the safeguard measures, both of which applied only during the transition period in which border barriers remained. Rules of origin are an essential ingredient of a free trade area in which the members retain their separate national tariff schedules and other border restrictions on trade vis-à-vis third countries. Article 3 of CER, 'Rules of Origin', occupies less than a page; NAFTA, in contrast, has almost 200 pages of rules not including the tables laying down the changes in tariff headings for individual tariff items. Similarly, the negatives list for service trade is more transparent than a positives list.

\footnotetext{
${ }^{4}$ The 50 per cent percentage rule which is the basis of the rules of origin does pose problems when an imported good is near the margin of 50 per cent, as changes in exchange rates, factor prices and factor
} 
A related feature of the CER is the total absence of any special court or other judicial or administrative body to monitor and enforce the Agreement. This is in marked contrast to, in particular, the EU, with its complex machinery of the European Commission, Parliament and Court. Instead, the Agreement emphasises consultation between the members. In this respect CER provides an alternative model. The absence of area-wide bureaucracies and legal enforcement bodies reflects the close historical ties between the two countries and the general similarities of their laws and legal and administrative procedures. New Zealand was one of the Seven Colonies (of Great Britain in the Antipodes) until Australia became a federal nation in 1901.

Another notable feature of the Agreement is that it has been accompanied by strong unilateral movement towards free trade and deregulation in both countries since the Agreement came into operation. For Australia, the average effective rate of assistance for all manufactures in 1982-83 was 23 per cent and this rate fell to only 12 per cent in 1992-93, the latest year available (Industry Commission, 1995: Table A1). For New Zealand, the more limited measures that are available show that the average effective rate of assistance for the manufacturing sector fell from 39 per cent in 1981-82 to 26 per cent in 1987-88, and it has fallen sharply since then (Syntec Economic Services, 1988, and Ministry of Commerce, 1991). Although free trade areas or customs unions approved under Article XXIV of the GATT are required only not to raise barriers vis-à-vis third countries, it is generally agreed that a lowering of such barriers is desirable to avoid trade diversion from third countries (see, for example, McMillan, 1993). No other regional trading arrangement has lowered trade barriers vis-à-vis third countries to the same extent as the countries of the CER. ${ }^{5}$ Thus CER is the outstanding example in this respect of the 'open regionalism' that is advocated by Australia and New Zealand in APEC and other forums. The main requirement of open regionalism is a lowering of barriers and trade facilitation vis-à-vis third countries (Garnaut \& Drysdale, 1994). Both Australia and New Zealand have regarded regional trade liberalisation as a supplement to their unilateral liberalisations and in particular as a way of making their economies more competitive in global markets.

\footnotetext{
efficiency can mean that a good fails to qualify. The rules were relaxed in the 1992 Review. While such problems are inescapable in a percentage rule, they would be reduced if the percentage were lowered to, say, 40 per cent, which is the number used in the ASEAN Agreement.

${ }^{5}$ The latest and most comprehensive time series of border assistance for Australia are in Industry Commission (1995). For New Zealand, GATT (1994) provides the latest in the GATT's annual reviews of changes in border assistance among the Contracting Parties. Regrettably, for other countries, there are no aggregate measures for the tradable sectors comparable to those of Australia and New Zealand. But one can still be certain that the dramatic lowering of trade barriers in the region has not been matched among other regional trading arrangements.
} 


\section{The Current Hesitation}

Since the 1988 Review progress in extending the Agreement has definitely slowed. The 1992 Review achieved far less than the 1988 Review and fell short of the agenda items for it that were announced by the two Prime Ministers in October 1991. There were ten agenda items: trans-Tasman shipping, taxation arrangements that impede bilateral trade and investment, aspects of the tariff and industry policies including a review of the rules of origin, a further review of the 1988 CER Trade in Services Protocol, further progress in business law harmonisation, trans-Tasman investment, further work on the harmonisation and mutual recognition of standards and other technical requirements, further work in harmonising customs and quarantine arrangements, border control procedures, and an examination of the mutual recognition of professional and other qualifications. Both governments considered that the three priority areas were trans-Tasman shipping, rules of origin and taxation, which were believed to involve particular impediments to freer trade.

Some ambitious proposals were seriously considered, notably a complete revision of the Double Taxation Agreement (with special arrangements for the tax treatment of trans-Tasman equity to eliminate discouragements or distortions of investments between the two countries), a trans-Tasman passenger pre-clearance (which would reduce the customs and passenger clearance from two inspections to one), and a Single Aviation Market.

The achievements of the 1992 Review were limited to amendments relating to the rules of origin, industry assistance and technical barriers to trade. The amendments to the rules of origin were restricted to the administration and transparency of these rules and they remain subject to interpretation and dispute. Work on technical standards was not completed and discussions on the harmonisation of the food standards systems continued in 1994. Negotiations on the Double Taxation Agreement were finally concluded in November 1994; but the new agreement does not include dividend imputation credits for business taxes, and companies with trans-Tasman equity continue to have some concerns because of differences in the tax structures of the two countries. For example, New Zealand has no capital gains tax. In relation to trans-Tasman shipping, the outcome was a statement that the two governments do not in any way support the maritime union accord and are satisfied that the relevant Australian and New Zealand legislation provides appropriate legal remedies if industrial action is taken in support of the accord. This is a feeble outcome compared with the straightforward option of banning the accord as a practice that restricts service providers, and is inconsistent with the movement towards free trade in services in the CER and the General Agreement on Trade in Services that was concluded in the Uruguay Round.

A Memorandum of Understanding on Air Services was signed on 1 August 1992. This was to establish a single aviation market covering the two countries from 1 November 1994. Aviation is an especially difficult area for agreement as transTasman flights are linked to a web of bilateral agreements by the two governments with third-country carriers and governments. The agreement was being phased in by each country securing beyond rights and capacity and the gradual opening of the 
Tasman routes. But in the week before the single market was to begin, the Australian government announced that it would not permit Air New Zealand to operate domestic services in Australia, ostensibly because New Zealand was not prepared to consolidate the airlines within a single market by merging Air New Zealand with Ansett. The New Zealand Prime Minister countered that the Australian government had acted to protect the value of the 1995 QANTAS share float. A single aviation market within the area has not been achieved. Air New Zealand has warned that it may consider legal action to gain the right to fly domestic routes within Australia.

There are now some outstanding areas that negotiations have not been able to resolve, chiefly the tax treatment of trans-Tasman equity, the incorporation of foreign investment into the CER and the single aviation market.

\section{Why Has CER Progress Slowed?}

Why has overall progress in extending the CER slowed down in the 1990s?

In the 1992 negotiations the New Zealand government was anxious to see the Agreement extended. For example, the New Zealand Minister for Trade Negotiations in October 1991 stated that 'New Zealand believes that our free trade agreement is imperfect so long as it does not apply fully to the movement of capital and trade in services the same rules that apply to movement of people and trade in goods' (Ministry of External Relations and Trade, 1992a:35). In another speech the Minister stated unreservedly that 'the [maritime] union accord must go' (Ministry of External Relations and Trade, 1992a:12). In contrast, speeches by Australian ministers during the 1992 Review were confined largely to a recital of facts and programs and avoided commitments to specific goals. (See the speeches in Department of Foreign Affairs and Trade, 1994). Australia saw the agreements as a free trade agreement which had been almost completed.

Spokespersons for the Australian government have advanced several reasons for the difficulties. One is that the CER trade preferences have declined relative to the trade barriers vis-à-vis third countries because of the unilateral reductions in MFN barriers by both countries and further steps "would intrude deeper into areas of economic policy traditionally regarded as outside the scope of trade agreements' (Urwin, 1994:3). The second development is the growth of opportunities in the wider Asia-Pacific and other markets. The third is 'the broad changes taking place in both our societies and politics' (Urwin, 1994:2).

The first argument - that these new issues encroach on policy areas that have traditionally been regarded as outside the scope of trade negotiations - is true historically but it is not correct now. Second-generation regional agreements that replaced earlier free trade agreements or customs unions in the 1980s and 1990s, such as the EU, EEA and NAFTA, all contain numerous provisions relating to the harmonisation of policies. The second argument - the emergence of wider market opportunities - does not by itself reduce the gains from bilateral trade liberalisation in relation to non-border instruments and the other outstanding issues. The 
third - on broad social changes - does not seem to have direct implications for the issues under debate in the CER.

In their examination of the politics of CER (concentrating on the 1992 Review), Eichbaum and Gerritsen (1993:518) argue that 'progress on the Agreement has reached a point where the "widening and deepening" of the relationship is contingent upon the nature of partisan coalitions within the domestic policies of the two CER partners'. They see the issues of harmonisation and further integration as part of the debate about microeconomic reform, an area of economic policy on which strong partisan differences exist in both countries. Attempts to harmonise the policies across the two countries are constrained by the domestic policy stances adopted by political parties. In particular, Eichbaum and Gerritsen see the Australian Labor Party as constrained by the stand it has taken in domestic political debates on these microeconomic issues. They also note these trans-Tasman differences have become more apparent since the election of the National Party government in New Zealand in October 1990. The 1992 Review was carried out during a period when the Labor Party has continued to govern in Australia, whereas the 1988 Review was carried out with Labo(u)r governments on both sides of the Tasman.

Partisan differences do not seem to explain the growing differences between the two governments' approaches to CER and in particular to the three major priority areas that were not resolved in the 1992 Review. Issues of trans-Tasman equity arise mainly from differences in tax structure. These are related in a very complicated way to the parties. For example, in Australia, both the present Labor Prime Minister and the Opposition under its previous leader, Dr John Hewson, proposed a move towards a New Zealand-style goods and services tax; but now both the Labor government and the Liberal Party are opposed to it, while both support dividend imputation. As for the single aviation market, this was first proposed by the present Australian government in One Nation statement of February 1992 as a part of a comprehensive package of microeconomic reforms and following the deregulation of the Australian aviation industry in October 1990. In the case of foreign investment, the long-standing bipartisan Australian view is that it is ruled out by the Basic Treaty of Friendship and Cooperation with Japan. The one issue in which party differences may have played a role is the maritime union accord in shipping, which an Australian Labor government would find more difficult to legislate against (though as it does not support the accord it may well like to scrap it!).

The party differences that have occasionally entered the trans-Tasman debate have mostly related either to microeconomic issues that are not part of the 1992 and current CER debates (such as the use of New Zealand shearers in Australian woolsheds or New Zealanders resident in Australia drawing unemployment benefits) or to macroeconomic policies that lie quite outside the range of issues considered for the CER (such as the changes made in New Zealand through the 1989 Reserve Bank Act, the 1991 Employment Contracts Act and the 1994 Fiscal Responsibility Act). The radical changes to the formulation of macroeconomic policies in New Zealand have produced a form of competition between the two governments that in turn has produced a trans-Tasman rivalry between politicians and civil ser- 
vants. During the campaigns for the last federal and Victorian State elections, Australian politicians criticised New Zealand legislation, prompting a vigorous response from the New Zealand Prime Minister.

Hence, the different views in Australia and New Zealand with regard to the extension of the CER stem from a combination of factors. The New Zealand government has been and remains more reformist than the Australian government with respect to both microeconomic and macroeconomic policies. In addition, the New Zealand economy is more open than Australia's in terms of the conventional ratio of the value of exports and imports of goods and services to GNP, and the proportion of its exports going to the trans-Tasman partner (20 per cent in 1994) is much higher than that for Australia (6 per cent in 1994). Consequently, it believes that it has more to gain from the greater integration of the economies. Furthermore, some of the outstanding CER issues do involve domestic policies (like foreign investment and tax policies) that are more difficult to harmonise across countries because they are complicated and impact on large parts of the national economies. Finally, competition between the national governments over the choice of macroeconomic policies does not provide a good atmosphere for the negotiation of CER matters even though it does not affect CER discussions directly.

\section{Is Greater Integration Desirable?}

The guiding principle on trans-Tasman integration should be the promotion of efficient production and exchange. The integration of trans-Tasman markets is important because it would eliminate the remaining barriers to the efficient allocation of resources within the area, though it could, in some cases, distort trade with other countries.

As an example of the benefits of integrating markets, consider restrictions on rights of establishment for foreign investors and unequal tax treatment. Producers in one country can increase sales of their outputs in the other country in two ways: by exporting the goods or by establishing affiliates in the other country, whichever is the more profitable. A direct link between trade and investment exists in the case of services that require the supplier to have a presence in the importing country. Indeed, for the world as a whole, the sales of foreign affiliates have surpassed exports as the principal vehicle of delivering goods and services to foreign market in the 1990s (United Nations Conference on Trade and Development, 1994:Table III.6). Limitations on rights of establishment restrict this choice and limit competition in commodity markets. Trans-Tasman barriers should be removed as they reduce competition and prevent primary factors from being allocated to the industries and locations where they have the highest marginal productivity. They also prevent the full benefits of the liberalisation of trans-Tasman trade in goods and services from being realised. Unlike commodity trade, the liberalisation of capital flows at the regional level does not pose problems of inefficient production due to discrimination, though liberalisation with respect to all countries would yield additional gains. (Other examples of possible benefits from greater integration of the two economies have been considered in Lloyd, 1991). 
Similarly, in civil aviation the problem is essentially how to increase the efficiency of airline operations in Australia and New Zealand so that the airlines may be more competitive on routes beyond the area while not reducing (but preferably increasing) competition within the area.

Some commodity and factor markets of Australia and New Zealand are still far from integrated. For example, energy policies and the role of the statutory marketing boards have not yet been examined as a part of the CER dialogue.

In each case, the concept of a single market provides a measure of the remaining distortions of trans-Tasman trade and investment, and a standard against which proposals can be compared.

\section{CER in the World Economy}

The second general question about CER is how it relates to trade policies in the rest of the world economy.

Major changes have occurred in the international trading regime in the last few years. In particular, the GATT Uruguay Round will result in a lowering of trade barriers multilaterally, and other regional agreements have been expanding in term of country membership and the scope of the instruments that are harmonised. At the November 1994 meeting in Bogor, the leaders of the APEC countries committed themselves in principle to open trade and investment among APEC countries by 2020. These developments pose new possibilities for the CER.

The achievements of the Uruguay Round and the promise of achievement under APEC have shifted the focus of Australian external trade policy further away from CER. It should be noted that the proportion of intra-area trade is lower for the CER countries than for other major regional trading arrangements. In particular, in 1993-94 - four years after the removal of all border barriers to transTasman trade - only 6.2 per cent of Australia's exports and 5 per cent of its imports were traded with New Zealand.

Other regional arrangements are changing more rapidly than ever before. Prior to the Bogor meeting, Singapore, a member of ASEAN and APEC, and Korea, another member of APEC, expressed interest in joining NAFTA, and New Zealand itself expressed interest in free trade arrangements with Mexico and Chile. In Miami in December 1994, 33 countries reached an agreement to form the Free Trade Area of the Americas (FTAA), initially by means of a new link between the Mercosur (the common market comprising Argentina, Brazil, Paraguay and Uruguay) and NAFTA free trade areas. Alarmed by discrimination against it that would result from this link, the EU has put more emphasis on the negotiations for a new link between the EU and Mercosur. The Canadian Prime Minister has called for a free trade area between North America and Europe that would link NAFTA and the EU. Suddenly, the development of new and larger regional trading areas that has been going on for the last ten years or so is entering a new phase of links between these areas.

One important possibility is a link between CER and AFTA. This was raised by Thailand with Australian and New Zealand Ministers in 1993 and then enthusi- 
astically promoted by the Australian Prime Minister during his visit to Thailand in early 1994. ${ }^{6}$ For more than a decade Australia has put primary emphasis in trade policy on relations with Asia and the Pacific; and New Zealand now similarly considers that its best economic prospects are in Asia (Ministry of External Relations and Trade, 1993). Official discussion to date has been limited to the exploratory talks between Australian, New Zealand and ASEAN officials held in 1995.

The AFTA-CER link needs to be considered in the context of global developments. FTAA may create serious problems for the APEC negotiations. This is partly because the US, Canada, Mexico and Chile, all members of APEC, may give priority to the Americas proposal and partly because there is a conflict between the unconditional MFN which is espoused by most APEC countries as a basis for the APEC negotiations and the conditional MFN (free trade area) in the FTAA proposal. The East Asian Economic Caucus might be revived. If the APEC free trade proposal does not proceed, an AFTA-CER link would become much more important. Such a link could give Australia and New Zealand improved and guaranteed market access to South-East Asia. It would also give Australia and New Zealand and ASEAN a greater say in the evolution of the world trading system.

At this stage it is not clear what form the link might take. In the preliminary talks it has been agreed that, in the initial stages, the discussions will be limited to APEC-style trade facilitation rather than trade liberalisation. (Trade facilitation covers areas such as customs, procedures, visa-free business travel, and industrial standards.) The greater gains, however, will come from trade liberalisation in the long run. A simple accession of CER to AFTA or of AFTA to CER is not likely to be acceptable to either group of countries; and in any case, the numerous differences between the two agreements make this impracticable. (Some of these differences are considered by the East Asian Analytical Unit, 1994:Section 9.2.3). Whereas CER has made substantial progress with the removal or simplification of nonborder policies, many border barriers remain within ASEAN; the removal of nonborder impediments to intra-area trade is limited to the harmonisation of standards; and reciprocal recognition of tests and certification has scarcely begun. The link would probably take the form of a supplementary agreement between the two arrangements.

An AFTA-CER link would probably have to be confined initially to border barriers to commodity trade. Reliable data on border barriers for the ASEAN countries is confined to the levels of tariffs on industrial products, which are higher than the averages in developed countries. The average applied MFN tariffs after the implementation of the Uruguay Round will remain high in all ASEAN countries

\footnotetext{
There has been some discussion in Fiji and other Pacific Forum countries about their membership of the CER. Article 24 of the Agreement provides for the accession of other states. However, the Pacific Forum countries receive the benefits of CER trade liberalisation under the SPARTECA Agreement. From the point of view of Australia and New Zealand, the Pacific economies are small, collectively as well as individually, and have natural barriers to trade because of distance. Their accession to CFR would, therefore, do little to increase efficiency in the Australian and New Zealand economies.
} 
other than Singapore, and in excess of 20 per cent for many agricultural, mining and manufacturing product groups that are of interest to Australia (Pangestu \& Stephenson, 1995:Table 3.2, provide statistics of average tariffs on product groups in the ASEAN countries). Barriers to imports into ASEAN countries of agricultural products are known to be high in some cases and numerous barriers to imports of services in ASEAN countries have been identified (see East Asian Analytical Unit, 1994:Appendix 4, for the latter).

Differences between the tariff structures of Australia and New Zealand on the one hand and some of the ASEAN countries on the other would pose some diffculties. However, large differences exist among the ASEAN countries such as Singapore and Indonesia or the Philippines, and these have not prevented the ASEAN countries from substantially freeing trade in manufactures, both unilaterally and regionally. Greater difficulties will arise with non-tariff border barriers. Negotiation of processed agricultural products and raw materials will also be difficult as these areas are still formally excluded from the trade liberalisation within AFTA. In these areas of trade policy, Australian and New Zealand unilateral action, with reforming instruments such as the tariffication of quantitative barriers by means of auctioning import quotas/licences and the reduction of assistance to agricultural producers, provides an example of successful methods of trade liberalisation. Service trade should be included in the link.

If the link could be extended beyond the negotiation of border barriers, the gains would be considerably increased. The CER experience of non-border instruments and other features such as the simple transparent rules of CER and the absence of a regional bureaucracy could also be useful. However, the similarity of the cultural and legal systems of Australia and New Zealand makes it difficult to extend policies to other countries in areas such as the harmonisation of competition policies and other areas of business law, bounties and subsidies, industrial and quarantine standards. Conversely, ASEAN experience in areas such investment rules and the development of sub-regional economic zones such as the IndonesiaMalaysia-Singapore and the Indonesia-Malaysia-Thailand growth triangles could be useful for the CER countries and the link. The removal of impediments to flows of capital is important, since direct foreign investment is an alternative and increasingly important way of supplying markets in other countries in the area and facilitates exports to third countries. In these areas, the ASEAN countries have been very adventurous in developing new policies for investment cooperation and infrastructure development.

\section{References}

Commission of the European Communities (1985), Completing the Internal Market White Paper from the Commission to the European Council, Brussels.

Council of Australian Governments and the Government of New Zealand (1995), A Proposal for the Trans-Tasman Mutual Recognition of Standards for Goods and Occupations: A Discussion Paper, AGPS, Canberra. 
Department of Foreign Affairs and Trade (1991), Australia New Zealand Closer Economic Relations Trade Agreement and Amending Documents, Canberra.

- (1994), Australian Statements on New Zealand, Canberra.

East Asian Analytical Unit (1994), ASEAN Free Trade Area: Trading Bloc or Building Bloc?, Department of Foreign Affairs and Trade, Canberra.

Eichbaum, C. \& R. Gerritsen (1993), 'The Impossible Politics of CER?', Australian Quarterly 65(1): $516-33$.

Garnaut, R. \& P. Drysdale (eds) (1994), Asia Pacific Regionalism: Readings in International Economic Relations, Harper Education, Sydney.

General Agreement on Tariffs and Trade (GATT) (1994), Intemational Trade and the Trading System, Geneva.

Industry Commission (1995), Australian Manufacturing Industry and International Trade Data 196869 to 1992-93, Canberra.

Lloyd, P. (1991), The Future of CER: A Single Market for Australia and New Zealand, Committee for Economic Development in Australia and the Institute of Policy Studies, Victoria University of Wellington, Wellington.

McMillan, J. (1993), 'Does Regional Integration Foster Open Trade? Economic Theory and GATT's Article XXIV', in K. Anderson \& R. Blackhurst (eds), Regional Integration and the Global Trading System, Harvester Wheatsheaf, Hemel Hempstead.

Ministry of Commerce (1991), Officials Report on the Post-1992 Tariff Review, Wellington.

Ministry of External Relations and Trade (1992a), CER: Key Documents and Speeches 1991/1992, Wellington.

— (1992b), CER Agneed Documents 1989.92, Wellington.

(1993), New Zealand Trade Policy: Implementations and Directions: A Multi-track Approach, Wellington.

Pangestu, M. \& S. Stephenson (1995), 'Evaluation of Uruguay Round Commitments by APEC Members', presented to the Pacific Economic Cooperation Council Trade Policy Forum VIII, Taipei, 20-21 April.

Syntec Economic Services (1988), Industry Assistance Reform in New Zealand, Sydney.

United Nations Conference on Trade and Development (1994), World Investment Report Transnational Corporations, Employment and the Workplace, United Nations, New York and Geneva.

Urwin, G. (1994), 'Australia-New Zealand: The Future of the Bilateral Relationship', in Department of Foreign Affairs and Trade, Australian Statements on New Zealand, Canberra.

I wish to acknowledge the helpful comments I received from officials from the New Zealand Section of the Department of Foreign Affairs and Trade, Tony Lynch of the New Zealand High Commission in Canberra and two referees. 